\title{
Belt Road Initiative in the Simulacra Analysis (Indonesia - China Relationship in the Perspective of Indonesian Students in Nanjing City)
}

\section{Belt Road Initiative dalam Analisis Simulakra (Hubungan Indonesia - Tiongkok dalam Perspektif Mahasiswa Indonesia di Kota Nanjing)}

\author{
Dani Fadillah \\ School of Communication and Journalism \\ Nanjing Normal University, China \\ Universitas Ahmad Dahlan \\ Email: dani.fadillah@comm.uad.ac.id
}

Jl. Kapas, Semaki, Umbul Harjo, Kotamadya Yogyakarta, Daerah Istimewa Yogyakarta

\begin{abstract}
The research analyzed the perspectives of Indonesian students that were located in Nanjing by using Jean Baudrillard's theory of simulacra. Recently, China had been trying to revive the silk road, a line connecting the world through trade, that used to be gainful in the past, with a route called the belt road initiative. This program had unlocked China's cooperation gates with many other countries from all over the world, although much undesirable information circulated regarding this initiative, ranging from environmental issues to rumor on the sovereignty of the state of China's partner. Through simulacra's logic, the author outlined the perspective of Indonesian students that had studied in Nanjing, China, towards the belt road initiative. The research found that even though the students had long felt education in China and assimilated much knowledge about this country quite first-hand, they did not necessarily believe that this new route would benefit their homeland.
\end{abstract}

Keywords: Belt Road Initiative; Indonesia - China; Simulacra

\begin{abstract}
Abstrak
Paper ini bertujuan untuk mengetahui bagaimana pandangan mahasiswa indonesia yang berada di kota Nanjing dalam perspektif Simulakra yang dibangun oleh Jean Baudrillad. Tiongkok tengah berupaya untuk kembali menghidupkan jalur sutera yang pernah eksis pada masa-masa kekaisaran zama dahulu, sebuah jalur yang menghubungkan dunia melalui perdagangan, kini jalur sutera baru itu bernama Belt Road Initiative dan telah membuka gerbang kerjasama Tiongkok dengan banyak negara dari berbagai penjuru dunia. Akan tetapi kemudian banyak informasi yang lantas beredar terkait Belt Road Initiative mulai dari isu lingkungan hidup hingga isu yang membahayakan kedaulatan negara yang menjadi rekan Tiongkok dalam Belt Road Initiative. Melalui logika Simulakra yang dibangun oleh Jean Baudrillad penulis ingin menjabarkan bagaimana perspektif para mahasiswa Indonesia yang telah mengenyam pendidikan di Kota Nanjing, Tiongkok terhadap program Belt Road Initiative yang tengah dikembangkan oleh negara yang menjadi lokasi belajar mereka ini. Hasil dari penelitian ini adalah meski sudah lama merasakan pendidikan di Tiongkok dan banyak mengetahui informasi tentang tiongkok langsung dari dalam negeri Tiongkok sendiri tidak menjamin bahwa mereka seratus persen yakin bahwa Belt Road Initiative baik bagi Indonesia.
\end{abstract}

Kata Kunci: Belt Road Initiative, Indonesia - Tiongkok; Simulakra. 


\section{Introduction}

When the Han dynasty ruled China from 206 BC to 200 AD, a route connecting the east and the west so-called the silk road used to be prosperous. This route connected the world by using the merchants as the connector with China as the center. This route infiltrated inter-nation borders. Through north Chinese road, this line penetrated eastern Europe and moved forward to the Black Sea and the Marmara Sea before eventually reaching the Balkan Peninsula. The south road expanded to Mesopotamia and Anatolia before hitting Egypt and North Africa (Indonesia.go.id, 2019). Southeast Asia, including the Archipelago, was also associated with the silk network and witnessed the impact. It was one of the rationales of the initial partnership between the Archipelago and China (Romdoni, 2019). However, as the world of politics and culture change, the silk road was not famous anymore, and the successful business activities within it started to dim.

In 2013, nevertheless, Xi Jinping, the Chinese President, initiated a notion to reawaken the new silk road, and it was named 一带一路 (read: Yi Dai Yi Lu) or internationally recognized as One Belt One Road (OBOR). This policy, which is now commonly called the Belt Road Initiative only, is proceeded as the Chinese government strategy to make China one of the most powerful countries on Earth. By taking control of trade routes, as carried out by Chinese Empires in the past, they believe that China would be worldly dominant (Muzakki, 2019).

China's strategy is not futile. Only by a reasonably short time, China has succeeded in being one of the most world's dominant states. Indeed, the amount of time it needs to procure the merits and advancements is deemed fast for a country. Furthermore, This country is also starting to dominate global economy competition regardless of the stiff competition. Not to mention that China is considered capable of competing with other dominant financial powers, such as the World Bank and the IMF. Gradually, China is starting to grasp supremacy as a superpower country, replacing the United States position that has been in the position mentioned for a long time (Fadillah \& Kumajaya, 2017).

However, not all camps accept a notion of belt road initiative happily. Although many countries from Russia Federation, South America, Europe, to Africa, have joined this trade road, some reservations on the consequences of this Chinese global partnership do still occur. Some risks that have been discussed range from debt-trap diplomacy for countries that partner with China to inadequate work standards in terms of the environment during infrastructure construction. This is because most of the deal between China and other nations are infrastructure development (CNN Indonesia, 2019). Even the World Bank alleged that China's economic strategy is the reason for which many countries are in debt.

As a country commencing on opening itself and providing numerous scholarship grants to international students, China is welcoming many people from all around the world to continue higher education in China, including those coming from Indonesia (Saptanti, 2017). Previously, another east Asia country that carried out the same strategy is Korea (Mulyana \& Eko, 2017). With that in mind, the researcher intends to grasp the perspective of Indonesian students that study in China towards the belt road initiative. This is because they do not only study but also elicit domestic information first-hand

Belt Road Initiative in the Simulacra Analysis (Indonesia - China Relationship in the Perspective of Indonesian Students in Nanjing City)

(Dani Fadillah) 
and receive Chinese Government Scholarship. Their perspective will be analyzed using Jean Baudrillard's theory of simulacra.

As a rule, for Baudrillard, simulacra is a condition happening in postmodern society. Baudrillard contended that, in postmodern, the world is replete with a new entity, so-called consumer society. They are individuals who voraciously ingest information produced by the media without highly weighing up that each message delivered by communication actor through media is a group of signs containing signifiers. Each sign and signifier is permeated with meaning capable of influencing the human mind and behavior (Baudrillards, 1988).

The low literacy of today's population in receiving media exposure can make them perplexed in the middle of the sea of information since the information produced by the media is copious (Lotan, 2019). In the post-modern era, information production cannot be confined. A message can be elicited anytime and anywhere, and those who are not well literate will be drowned in the wave of agenda-setting game set by communication actors (Ulfah, Fajri, \& Fadillah, 2017). Indeed, the new species named consumer society is poorly literate.

In the logic of simulacra, each communication actor is keen on playing simulation by creating his reality that could be juxtaposed with organic reality. Consumer society sometimes is imprisoned in reality developed by those communication actors and, at some point, believes that it is the real organic reality. Furthermore, after living in an artificial fact for some time, three possibilities commonly occur. Firstly, they might be more deluged in that realm and apt to think they live in the real truth. Secondly, they endeavor to escape and discover the actual organic reality. Thirdly, they escape from the artificial reality but are re-imprisoned to the reality they wish to run away (Baudrillard, 2017).

Nevertheless, regardless of what choice consumer society pick, they eventually will be incapable of discriminating between artificial and organic reality. Since the postmodern world has been full of simulated reality, everything seems to be mixed, and the organic world seems not to exist anymore. At this level, humans are living in a hyperreality. In a hyper-reality, the simulated world appears more tangible than the organic world (Khushendrarpwati, 2011).

The low literacy of consumer society when receiving information and media exposure becomes an opportunity for communication actors (and sometimes political actors) to impose a particular value to society. It is expected to be a simulation that can be believed by more people as the real reality and cand be used for a specific purpose (J. Schor, Holt, \& Holt., 2000). Admittedly, consumer society realizes that they will reap some negative logical consequences when they are trapped in that reality. However, it appears that whatever results they will undergo, they will seemingly enjoy it (Douglas Kellner, 2007).

To that end, the researcher attempts to understand Indonesian students' perspectives studying in Nanjing, China, towards the belt road initiative in light of Jean Baudrillard's theory of simulacra. Besides Indonesia is a country that has partnered with China in the form of the belt road initiative (Minoru Iwasaki, 2017), they were picked because those students had received much information on the belt road initiative from various sources, including news coming from domestic sources. 


\section{Methodology}

The research was qualitative descriptive research. In the research, the researcher carefully and sincerely conducted data collection, data analysis, and data interpretation to ensure that the information collected could sufficiently base the result identification process and outcome. This step was carried out until a formulation, which referred to the analysis, was drawn (Sugiyono, 2013).

The number of Indonesian students that stayed in Nanjing that were successfully tracked by the researcher was 488 students. They consisted of students that study in vocational school, undergraduate level, post-doctoral level, and those who came for mastering 普通话汉语 (read: putonghua han yu/ standard Chinese) for one year program. The researcher handed out questionnaires and conducted in-depth interviews in a discussion forum to gather their opinion about the belt road initiative after studying in China and obtaining much information about this policy and strategy from the national media.

The researcher also identified various media coverage on the belt road initiatives for discussion material during the interview. Following this, the data that the researcher had been collected from the interviews and questionnaires were analyzed using Jean Baudrillard's theory of simulacra.

\section{Results and Discussion}

Based on the data collection analysis using Baudrillard simulacra toward the belt road initiative from the perspective of Indonesian students in Nanjing, these results were found.

Firstly, a group of students that believed that the Indonesia-China relationship in the form of the belt road initiative had a positive effect on Indonesia. They who thought so were mostly Indonesian students that acted as either the steering or the executive committee of the Indonesian Student Association of China, Nanjing branch.

Based on the questionnaire and interviews the researcher conducted, the informants opined that they had read many progress note and welfare target that could be procured by Indonesia in terms of education to infrastructure if they followed the rules and guidelines of the belt road initiative correctly. They also had received socializations from officials from the Indonesia Embassy in Beijing and the Directorate General of Republic Indonesia in Shanghai concerning the same program.

They also voiced their reservations on negative consequences that might occur from the belt road initiative. It indicated that although they believed in this program, they still kept a certain amount of doubt. For example, when they were asked to discuss news published by JPNN.com entitled "five years of silk road program, eight countries were trapped by China" (19/08/2018) (Jawa Pos, 2018) and by Tirto.id entitled "Expansion of the Chinese OBOR program, the government were asked to be careful with debt-diplomacy trap (02/05/2018) (Adhi Bhaskara, 2019). They argued that that news was a collection of valid skepticism and fear and would happen if the elected officials erroneously executed the project agreed.

They contended that if the Indonesian government is alert and chose the accurate steps in executing the projects, everything will be fine. Even it will benefit Indonesia and citizens. They believed that it was a dream that should look optimistically, as voiced by Wahyuddin, one of the committees of the Indonesian Student Association of China,

Belt Road Initiative in the Simulacra Analysis (Indonesia - China Relationship in the Perspective of Indonesian Students in Nanjing City)

(Dani Fadillah) 
in his writing entitled "Accelerating the improvement of Indonesian education standard through the belt and road initiative program" (Wahyuddin, 2019). In that work, he argued that many Indonesian projects with China, including infrastructure, could accelerate the quality of Indonesian education. Considering that the quality of many Indonesian schools was still below the standard, some points of agreement in Indonesia-China partnership in the form of belt road initiative would be beneficial.

These students also contended that the Indonesian government would be cautious in executing the belt road initiative and would not be trapped in debtdiplomacy. It was in line with news published in iNews.id entitled "Joining in the OBOR project, Luhut guarantees Indonesia will not fall in debt-trap" (09/05/2019) (Antara, 2019). They said that Indonesia was not a new country or country that was easy to manipulate. Indonesia, conversely, had been experienced in international partnerships with many countries. They believed that the Indonesian government possessed numerous strategies to avert the debt trap.

Applying Baudrillard's theory of simulacra, what expressed by the informants could be analyzed as follows: there was a simulation that the belt road initiative was not a trap but a joint multilateral partnership. Indonesia had developed much cooperation similar to this with different names. Nothing, therefore, can be afraid of the belt road initiative. The officials that wielded power were merely required to follow the supposed rules. Also, they needed to prioritize Indonesian pride as China's associate and not being the beggar of China.

This simulation actuated a reality in their perception that this cooperation was not harmful. However, while it was possible to say that this partnership would give Indonesia merits, saying that it had a zero-risk was reasonably uncritical. Under no circumstances did agreement without risk exist, but, in this vein, the reality established is that China did not plan to ambush Indonesia but offered an opportunity that may make Indonesia more triumphant in the future.

A hyper-reality then appeared that the Indonesian government had prepared any plausible possibilities so carefully that it would be impossible for Indonesia to get tricked, even if the trap was real. Had Indonesia anticipated any worst scenarios? As an experienced country in much international partnership, admittedly, that anticipation must have existed. However, was it impossible the government miscalculated something? It would still be possible they miscalculated some events. Nevertheless, a hyper-reality had been born and asserted that the government had prepared any scenarios so cautiously that no reservations needed to exist.

Secondly, a group of students that worried that the relationship between Indonesia and China in the form of the belt road initiative might lead Indonesia to undesirable consequences. They were afraid that the partnership might give undemanded effects for Indonesia. Some of them also committee in the Indonesian student association of China, but what made them different is that they were also activists of Indonesian citizen organizations that resided in Nanjing.

Based on the data, they were convinced that news on countries that were caught on the debt-diplomacy trap and went on bankruptcy could not be set aside. This is because those countries must have had many economic agreements with other countries too. However, why did they undergo many economic problems when they partnered with China. It raised a question.

Furthermore, for them, the future of Indonesia would not be more prosperous with the belt road initiative. They were hoping that the ideal progress offered by the belt 
road initiative can be realized. However, this agreement did still breed a certain skepticism, mostly owing to the pervasive domination of China and the potential of China to be a superpower country. They believed that, in general, a superpower had the drive to subjugate other regions, whether militarily or economically.

The belt road initiative was a perfect ambush. Whereas military intervention would induce the invader to put up with severe international sanctions, not to mention that other countries would unite to chase the country that wage military intervention, economic intervention posited intervened country to be guilty. Those countries would be accused incapable of performing partnership and eventually would lead them in debt and national downturn.

To confirm that, the students were asked to discuss news published on detik.com entitled "Here are the silk road projects run by China" (29/03/2019) (Puti Aini Yasmin, 2018) regarding the long-term effect that would be acquired by countries joined in the belt road initiative, and news from liputan6.com entitled "wanting to follow China creating the new silk road, Italy upsets the USA and EU (21/03/2018) (Utomo, 2019) regarding the increasing number of camps that joined with China in the belt road initiative. The way they saw it, it was not a guarantee that the belt road initiative was completely clean.

Indeed, they asked the researcher to also highlighted the news in liputan6.com, named "a list of undesirable consequences of China silk road project for Indonesia" (26/04/2019) (Yayu Agustini Rahayu, 2019). They argued that Indonesia was not supposed to be satisfied with sweet dreams offered by China in the form of the belt road initiative since the detriment was apparent and has been experienced by countries that were traped to accept China's offers.

Applying Baudrillard's theory of simulacra towards their perceptions on Indonesia - China relationship, it can be analyzed as follows. There was a simulation that China that had experienced a rapid improvement had a desire to control the world. This is the reason for which the path they should put up with was by subjugating other surrounding nations.

From that simulation, a reality saying that China would take control over the world and conquer other countries using a program called the belt road initiative was created. However, while it is possible for China to earn benefits from the belt road initiative, saying that China would take over the world was questionable. The reason is that the purpose of international cooperation and investment was mainly for economic aim, and each nation had a desire to be the most dominant one. However, in this vein, that was the reality that has been entered by Indonesian students that were worried about the belt road initiative.

Subsequently, a hyper-reality appeared that countries that accepted Chinese offer to join in the belt road initiative would go bankrupt and trapped in inexorable debt. However, while it was accurate that some countries were in debt after accepting the belt road initiative partnership, the number was so limited. Also, while some states were in debt, it was hard to concede that the belt road initiative was the only reason for that. It may occur because of external factors, such as unstable domestic conditions, and so on. Nevertheless, the students had entered a reality saying that the belt road initiative could only bring a country to a disaster.

Belt Road Initiative in the Simulacra Analysis (Indonesia - China Relationship in the Perspective of Indonesian Students in Nanjing City) 


\section{Conclusion}

Indonesian student's perspective in China on the belt road initiative issue is an example of that living in the same space and studying in a quite long time was not a guarantee that they would be in the same opinion toward an issue associated with the country the lived in. Differences in choosing references affect their mindset (Fadillah, 2014), notably considering that their recommendations mostly were the internet that was capable of producing sign relentlessly. With that in mind, the internet could affect the audiences more effective than other conventional media (Jandevi, 2019). Not to mention that news published in online media was still questionable, especially the objectivity and credibility (Widodo, 2010).

Besides, the preferences of colleagues to discuss the issue were also influential. On average, there were differences in the pattern of thought and perception between those that were active in an organization and those who were not involved in any organization. Organization and the members within it contributed to the discourse choices and behavior of someone. Each individual would provide a different stimulation in each discussion (Fadillah, 2015).

\section{Acknowledgments}

The researcher would like to express her deepest gratitude to Universitas Ahmad Dahlan, Nanjing Normal University, Indonesian Student Associaton of China Nanjing Branch, and board directors of Muhammadiyah of Nanjing, that have assisted the researcher in conducting the research. Their assistance from the data collection process to preparing the report made the work successfully be arranged and published. The researcher also would like to thank Jurnal Aspikon that allowed this article to be published. The researcher hopes that this work brings benefits to everyone.

\section{References}

Adhi Bhaskara. (2019). Ekspansi proyek Obor Cina, Pemerintah Diminta waspadai Jebakan Utang. Retrieved from Tirto.Id website: https://tirto.id/ekspansi-proyekobor-cina-indonesia-diminta-waspadai-jebakan-utang-dnpo

Antara. (2019). Ikut Proyek OBOR, Luhut Jamin Indonesia Tidak Masuk dalam Jebakan Utang China. Retrieved from iNews.id website: https://www.inews.id/finance/makro/ikut-proyek-obor-luhut-jamin-indonesiatidak-masuk-dalam-jebakan-utang-china/538841

Baudrillards, J. (1988). Selected Writings (Mark Poster, Ed.). Stanford: Stanford University Press.

CNN Indonesia. (2019). Bank Dunia Sebut Proyek Jalur Sutra China Berisiko. Retrieved from CNN Indonesia website: https://www.cnnindonesia.com/ekonomi/20190619094537-92-404498/bank-duniasebut-proyek-jalur-sutra-china-berisiko?

Douglas Kellner. (2007). Jean Baudrillard. Retrieved from Stanford Encyclopedia of Philosophy website: https://plato.stanford.edu/entries/baudrillard/

Fadillah, D. (2014). Strategi komunikasi pembentukan budaya organisasi. Humanika, 14(1). https://doi.org/https://doi.org/10.21831/hum.v14i1.3327

Fadillah, D. (2015). Model Komunikasi "WOM" Sebagai Strategi Pemasaran Efektif. Humanika, 15(1). https://doi.org/https://doi.org/10.21831/hum.v15i1.7642

Fadillah, D., \& Kumajaya. (2017). Lompatan Strategis China Dalam Komunikasi Global. Yogyakarta: Samudra Biru. 
Indonesia.go.id. (2019). Jalur Sutera Abad 21, Apa Untungnya? Retrieved from Indonesia.go.id website: https://indonesia.go.id/narasi/indonesia-dalamangka/ekonomi/jalur-sutera-abad-21-apa-untungnya

J. Schor, Holt, B., \& Holt., D. (2000). The Consumer Society Reader. US: New Press.

Jandevi, U. (2019). New media for increasing political participation in Indonesia. International Journal of Communication and Society, 1(1), 1-8. https://doi.org/10.31763/ijcs.v1i1.19

Jawa Pos. (2018). 5 Tahun Program Jalur Sutra, 8 Negara Masuk Jebakan Tiongkok. Retrieved from JPPN.Com website: https://www.jpnn.com/news/5-tahun-programjalur-sutra-8-negara-masuk-jebakan-tiongkok

Jean Baudrillard. (2017). The Consumer Society Myth and Structures. California: Sage Publication.

Khushendrarpwati, S. margaretha. (2011). Hiperealitas dan Ruang Publik, Sebuah Analisis Culturasl Studies. Jakarta: Penaku.

Lotan, F. F. (2019). Making a positive internet through Socmed Agawe Guyub. International Journal of Communication and Society, 1(1), 9-16. https://doi.org/10.31763/ijcs.v1i1.22

Minoru Iwasaki. (2017). Jokowi dan XI Jinping Restui Tiga Kerja Sama Baru. Retrieved from CNN Indonesia website: https://www.cnnindonesia.com/internasional/20170514213858-106214767/jokowi-dan-xi-jinping-restui-tiga-kerja-sama-baru

Mulyana, D., \& Eko, B. S. (2017). Indonesian Students' Cross-Cultural Adaptation in Busan, Korea. ASPIKOM, 3(2), 144-156. Retrieved from http://jurnalaspikom.org/index.php/aspikom/article/view/135/110

Muzakki, F. (2019). Di Balik Layar Projek Global: Latar Belakang, Motivasi, dan Cakupan Inisiative "Belt and Road." In F. Muzakki (Ed.), Indonesia dalam The Belt and Road Initiative (pp. 8-19). Jakarta: PPI Tiongkok.

Puti Aini Yasmin. (2018). Ini Proyek-proyek Jalur Sutra yang Digarap China. Retrieved from Detik.Com website: https://finance.detik.com/infrastruktur/d-4488898/iniproyek-proyek-jalur-sutra-yang-digarap-china

Romdoni, A. (2019). Inisiatif Belt and Road: Dari Pengetahuan Lokal ke Kesejahteraan Global. In F. Muzakki (Ed.), Indonesia dalam The Belt and Road Initiative (pp. 20-31). Jakarta: PPI Tiongkok.

Saptanti, I. R. (2017). Ni Hao, Nanning. Jakarta: PT Inspirator Juara Indonesia.

Sebayang, R. (2019). Apa Itu OBOR, Jalur Sutra Modern China yang Jadi Polemik RI? Retrieved from CNBC Indonesia website: https://www.cnbcindonesia.com/news/20190513181838-4-72178/apa-itu-oborjalur-sutra-modern-china-yang-jadi-polemik-ri

Sugiyono. (2013). Manajemen Metode Penelitian. Yogyakarta: Alfabeta.

Ulfah, M., Fajri, C., \& Fadillah, D. (2017). Pemahaman Literasi media Di Lingkungan Pengurus Pimpinan Wilayah Aisyiyah daerah Istimewa Yogyakarta Periode 20152020. Informasi, $47(2)$. https://doi.org/https://doi.org/10.21831/informasi.v47i2.16574

Utomo, H. F. S. (2019). Ingin Ikut China Membangun Jalur Sutera Baru, Italia Bikin Gerah AS dan Uni Eropa. Retrieved from Liputan6.com website: https://www.liputan6.com/global/read/3922727/ingin-ikut-china-membangun- 
jalur-sutera-baru-italia-bikin-gerah-as-dan-uni-eropa

Wahyuddin. (2019). Akselerasi Peningkatan Mutu Pendidikan di Indonesia Melalui Program The Belt and Road Initiative. In Fadlan Muzakki (Ed.), Indonesia dalam The Belt and Road Initiative (pp. 71-84). Jakarta: PPI Tiongkok.

Widodo, Y. (2010). Menyoal Etika Jurnalisme Kontemporer: Belajar dari OhmyNews. ASPIKOM, 1(1), 41-59. Retrieved from http://jurnalaspikom.org/index.php/aspikom/article/view/7/4

Yayu Agustini Rahayu. (2019). Daftar Dampak Buruk Proyek Jalur Sutra China bagi Indonesia. Retrieved from Liputan6.com website: https://www.liputan6.com/bisnis/read/3952852/daftar-dampak-buruk-proyek-jalursutra-china-bagi-indonesia 